\title{
MaAhanmuUtTajien OHJAUS TYÖVOIMA- HALLINNOSSA JA AIKUISKOULUTUKSESSA - KOHTI INTERKULTTUURISTA OHJAUSTA
}

\author{
Eine Pakarinen: YTT, yliopistonlebtori, Ybteiskuntatieteiden laitos, Itä-Suomen yliopisto \\ eine.pakarinen@uef.fi \\ Janus vol. 27 (2) 2019, $\mathrm{xxx}-\mathrm{xxx}$
}

JOHDANTO

Maahanmuuttajien ohjaus on monikulttuurista ohjausta, jossa kulttuurinen erilaisuus on keskeinen lähtökohta ja jossa pyritään kaikissa vaiheissa ottamaan huomioon kulttuurieroista nousevat haasteet etsittäessä yhdessä maahanmuuttajan kanssa ratkaisuja hänen kysymyksiinsä (Puukari \& Korhonen 2013, 16).Väitöskirjani käsittelee maahanmuuttajien ohjausta työvoimahallinnossa ja aikuiskoulutuksessa tuoden esiin ohjausta antavien työntekijöiden kokemukset. Tutkimukseni kohderyhmänä ovat työvoimahallinnon ja aikuiskoulutuksen työntekijät. He ovat keskeisiä henkilöitä maahanmuuttajien ohjauksessa, kun kyseessä on maahanmuuttajien kotoutuminen heidän työllistymisensä näkökulmasta. Työntekijöiden kokemus maahanmuuttajille annatusta ohjauksesta on keskeinen asia kehitettäessä maahanmuuttajien ohjausta.

Tutkimukseni empiirinen aineisto muodostuu kvalitatiivisesta ja kvantitatiivisesta tutkimusaineistosta. Kvalitatiivisena tutkimusaineistona on työvoimahallinnon ja aikuiskoulutuksen työntekijöiden teemahaastattelut $(n=24)$ Itä-Suomen alueelta. Kvantitatiivisena aineistona on valtakunnallinen verkkokysely $(n=173)$ työ- ja elinkeinotoimistojen ja aikuiskoulutuksen työntekijöille. Kvantitatiivisen aineiston vastausprosentti on 65,3 . Kvalitatiivinen aineisto on analysoitu sisällönanalyysilla ja kvantitatiivinen aineisto tilastollisin testein muun muassa faktorianalyysin avulla.

Lähestymistapani tutkimukseen sisältää aineksia erilaisista teoreettisista tarkastelutavoista. Tutkimuksen taustoituksessa tarkastelen suomalaista maahanmuuttopolitiikkaa ja suomalaisten työmarkkinoiden kehittymistä sekä maahanmuuttajien työmarkkinaasemaa ja työllisyyttä Suomessa. Maahanmuuttopolitiikassa nähdään tärkeänä maahanmuuttajien kotoutuminen. Maahanmuuttajien kotoutumista auttaisi heidän työllistymisensä. Samalla työllistyminen ehkäisisi heidän syrjäytymistään suomalaisesta yhteiskunnasta, jossa työllä on suuri merkitys elintason, sosiaalisen statuksen ja täysivaltaisesti yhteiskuntaan osallistumisen kannalta. Maahanmuuttajien työmarkkina-asema ei kuitenkaan ole tällä hetkellä hyvä. Tämän seikan parantaminen asettaa haasteita maahanmuuttajien ohjaukselle työvoimahallinnossa ja aikuiskoulutuksessa, sillä kotoutuakseen ja työllistyäkseen maahanmuuttajat tarvitsevat ohjausta.

Tutkimukseni teoreettinen viitekehys rakentuu ohjauksen ja ohjauksen orientaatioiden teoreettisesta tarkaste- 
lusta. Tutkimuksessani tarkastelen ohjausta toimintana, jossa työn kohteena on maahanmuuttajien ohjaus. Työn tavoitteena on maahanmuuttajien kouluttautuminen, työllistyminen ja sitä kautta kotoutuminen sekä näin syrjäytymisen ehkäiseminen. Tutkimuksessani paikannan maahanmuuttajien ohjauksessa esiintyviä orientaatioita. Orientaation miellän teoreettiseksi lähestymistavaksi, joka tulee esiin työntekijän ohjauksessa käyttämissä työskentelymenetelmissä. Tällöin voidaan puhua myös työorientaatiosta, joka tarkoittaa konkreettista ohjausprosessia rakentavaa metodista toimintamallia.

Tutkimusta maahanmuuttajien ohjauksesta on tehty niin kansainvälisesti kuin kansallisesti. Maahanmuuttajien ohjauksessa esiintyviä orientaatioita taas on tutkittu vähemmän. Ohjauksen teoreettinen lähestymistapa tutkimuksessani on psykodynaaminen, kognitiivis-behavioraalinen ja eksistentiaalis-humanistinen. Nämä ovat kolme keskeistä ohjauksen teoreettista tarkastelutapaa ohjauksen orientaatioista tehdyissä tutkimuksissa (esim. Jensen ym. 1990; Worthington \& Atkinson 1993; Constantine 2001; Norcross et al. 2002; Worthington \& Dillon 2003). Näiden lähestymistapojen lisäksi tutkimuksessani on mukana konstruktivistinen ja interkulttuurinen orientaatio. Konstruktivistinen orientaatio on yleistynyt viime aikoina ohjauksessa, sillä uudet teoriat ohjauksessa korostavat konstruktivistisuutta (Kuusinen 2000, 96). Myös tutkimuksessani työntekijöiden haastatteluissa tuli ilmi, että heidän saamansa koulutus monikulttuurisesta ohjauksesta pohjautuu pitkälti Peavyn (1999) kehittelemään sosiodynaamiseen ohjaukseen, joka perustuu kon- struktivistiseen teoriaan. Konstruktivistinen orientaatio tukee nykyistä ohjauskäsitystä,jossa keskeistä on ohjattavan oma aktiivisuus. Interkulttuurinen orientaation on mukana siksi, että se edustaa uudenlaista modernia kansainvälistä globaalin ajan orientaatiota, jossa painopiste on kulttuurien välisessä vuorovaikutuksessa ja jonka orientaatioperusta koostuu erilaisista teoreettisista suuntauksista.

Tutkimuksessani keskeisiksi teemoiksi muodostuivat 1) ohjauksen orientaatiot, 2) ohjaajien ammattikäytännöt ja ammatilliset taidot maahanmuuttajien ohjauksessa sekä 3) maahanmuuttajien ohjausprosessi. Näiden teemojen pohjalta tarkentui kolme tutkimuskysymystä: Millaisia ohjauksen orientaatioita on tunnistettavissa maahanmuuttajien ohjauksessa? Miten ohjauksen orientaatiot ilmenevät työvoimahallinnon ja aikuiskoulutuksen työntekijöiden ammattikäytännöissä maahanmuuttajien ohjauksessa? Millaisia kehittämistarpeita on tunnistettavissa maahanmuuttajien ohjauksessa?

\section{OHJAUKSEN ALKU-, TYÖSKENTELY- JA ARVIOINTIVAIHEEN ORIENTAATIOT}

Tutkimukseni tulosten mukaan maahanmuuttajien ohjauksen alku-, työskentely- ja arviointivaiheessa on paikannettavissa työntekijöiden toiminnasta, ammattikäytännöistä, ammatillisista valmiuksista ja taidoista seuraavat ohjauksen orientaatiot: psykodynaaminen, konstruktivistinen, kognitiivis-behavioraalinen ja interkulttuurinen. 
Tutkimukseen osallistuneille työntekijöille alkuvaiheen ohjaus olikin erityisen tärkeä, sillä alussa maahanmuuttaja tarvitsee paljon erilaista konkreettista ja informatiivista ohjausta. Ohjaaja toimii lähinnä pragmaattisena tukena maahanmuuttajalle neuvojen antajana. Maahanmuuttajien ohjauksen alkuvaiheessa korostui vahvasti ohjaajan auktoriteettiasema, kun vastavuoroista ohjaussuhdetta ei vielä ollut syntynyt maahanmuuttajan kanssa. Tällöin ohjattavat tarvitsevat auktoriteettihahmon antamaan selvät suunnat, mitä tehdä ja miten tehdä. He kokevat ohjaajan asiantuntijana. (Grow 1996; Lehtinen \& Jokinen 1996, 35-38.) Tässä on tunnistettavissa sama ilmiö kuin sosiaalityössä eli liittämis- ja kontrollisuhde (Juhila 2006, 99) sekä asiantuntijakeskeinen orientaatio (Mönkkönen 2002). Alkuvaiheessa ohjauksessa käytettyinä työmuotoina korostuvat erityisesti asioiden selvittäminen ohjattavan puolesta ja kädestä pitäen ohjaus. Tällöin ohjauksen orientaatiopohjan perustana on kognitiivis-behavioraalinen orientaatio.

Alkuvaiheen ohjaukseen sisältyy maahanmuuttajan elämäntilanteen, ammattikokemuksen, koulutuksen ja harrastusten kartoittaminen, tavoitteiden asettaminen ja suunnitelman tekeminen. Maahanmuuttajien osaamisen tunnistamiseen olisi varattava riittävästi aikaa. Nettikyselyyn vastaajista yhdeksän kymmenestä oli täysin tai osittain sitä mieltä, että maahanmuuttajilla on paljon osaamista, jota voisimme suomalaisessa työelämässä tarvita. Maahanmuuttajien ohjaus olisi rakennettava hyvin, jotta ei hukattaisi koulutus- ja osaamispääomaa, jota monella maahanmuuttajalla on. Tutkimukseni aikana keräämissäni maahanmuuttajien alkuohjauksen dokumenteissa, työvoimahallinnon kotoutumissuunnitelmissa ja aikuiskoulutuksen henkilökohtaisissa opintosuunnitelmissa ei vielä ollut kirjattuna esimerkiksi maahanmuuttajien kiinnostuksen kohteita ja harrastuksia. Tutkimukseni aineisto sijoittuu vuosille 2007-2009, jolloin oli vielä voimassa edellinen kotoutumislaki (Laki maahanmuuttajien kotouttamisesta ja turvapaikanhakijoiden vastaanotosta 493/1999). Uudessa kotoutumislaissa $(1386 / 2010)$ on määritelty erikseen maahanmuuttajien alkukartoitus ja alkukartoituksen järjestäminen. Jatkossa olisi mielenkiintoista nähdä, onko kotoutumislain uudistaminen alkukartoituksen osalta vaikuttanut maahanmuuttajilta alkuvaiheessa kerättävien tietojen kirjaamiseen, sillä kotoutumislain tärkeä tavoite on tehostaa maahanmuuttajien ohjautumista sekä perus- että kotoutumista edistäviin erityispalveluihin. Alkuvaiheen palveluiden pitkäjänteisen ohjauksen avulla voidaan tukea siirtymiä koulutukseen, erilaisiin työllistymistä edistäviin palveluihin ja työelämään. (Sisäministeriö 2015, 69-71.)

Alkuvaiheen ohjauksen jälkeen työskentelyvaiheessa ohjaajan roolina on toimia auttajana ja motivoijana, jolloin ohjaajan toiminnassa näkyy emotionaalinen ja tietotuki. Ohjaaja toimii kuuntelijana ja auttajana. Tässä on tunnistettavissa samoja piirteitä kuin sosiaalityön huolenpitosuhteessa (Juhila 2006, 198-199) sekä asiakaskeskeisessä orientaatiossa (Mönkkönen 2002). Tällöin ohjauksen orientaatiopohjan perustana on paikannettavissa psykodynaaminen orientaatio. Ohjaajan toiminta painottuu emotionaaliseen ja tietotukeen maahanmuuttajalle. Psykodynaamisessa orientaatiossa ohjaaja on kuuntelija ja 
auttaja. Työskentelyvaiheessa ohjauksen edetessä pyritään ohjauksessa tasavertaiseen kumppanuuteen keskustelussa ja toiminnassa maahanmuuttajan kanssa. Tällöin ohjauksen orientaatiopohjana on konstruktivistinen orientaatio ja ohjaaja toimii reflektiotukena maahanmuuttajalle. Ohjaaja on tasavertainen kumppani ohjattavan kanssa keskustelussa ja toiminnassa. Tällainen suhde kuvastaa sosiaalityön kumppanuussuhdetta (Juhila 2006) sekä dialogista orientaatiota (Mönkkönen 2002).

Tutkimuksessani työntekijät kuvasivat vastauksissaan, että maahanmuuttajien ohjauksessa tärkeää on kohdata ihminen ihmisenä. Tällöin asiantuntijuus nähdään horisontaalisena, joka tarkoittaa samalle tasolle asettumista ja toinen toisensa kuulemista. Työntekijän ja asiakkaan suhde on tällöin tasavertainen kumppani-kumppani-asetelma, jossa kummatkin osapuolet saavat äänensä kuuluviin ja lähtökohtansa huomioon otetuiksi (Juhila 2006, 138, 147). Tällöin dialogisessa orientaatiossa vuorovaikutus tapahtuu molempien ehdoilla ja eriäänisyys pyritään kutsumaan esiin (Mönkkönen 2002, 63). Juhila $(2006,118)$ on myös luonnehtinut tätä kumppanuussuhteeseen perustuvaa toisen tiedot ja erot lähtökohdakseen ottavaa sosiaalityötä osallistavaksi. Tällöin asiakkaat osallistavat työntekijöitä omaan tietoonsa ja työntekijät puolestaan pyrkivät tukemaan asiakkaiden elämänpoliittisia ratkaisuja tavalla, joka mahdollistaisi heille heidän mahdollisesta marginaalisuudesta huolimatta täysivaltaisen kansalaisuuden. Tutkimukseni tuloksissa tämä kävi ilmi siinä, että työntekijät halusivat miettiä maahanmuuttajille sopivia koulutus- ja työmahdollisuuksia, jos se vain käytet- tävissä olevien resurssien puitteissa on mahdollista. Ohjauksessa käytettyinä työmuotoina alkuohjauksen jälkeen käytettiin paljon keskustelua ja jonkun verran neuvomista. Ohjauksen edetessä kädestä pitäen näyttäminen vähenee.

Maahanmuuttajien ohjausprosessiin kuuluu keskeisesti myös arviointi. Arvioinnissa ollaan usein tekemisissä ihmisten elämää monella tapaa koskettavien ilmiöiden kanssa, ja siksi arvioinnin vähimmäisvaatimuksena on, että se on toteutettu korkealaatuisesti ja eettisesti vastuullisesti. Ajallisesti arviointia voidaan tehdä etukäteisarviointina, jatkuvana ja jälkikäteisarviointina.Yleisimpiä käytäntöjä ovat jatkuva ja jälkikäteisarviointi. (Lindberg 2013, 21.) Problemaattiseksi arvioinnin tekee, että arviointiin ei välttämättä osallistu ohjattava esimerkiksi kielitaidon puutteen vuoksi tai ohjattava on hyvin auktoriteettiuskoinen tai maahanmuuttajilla esiintyy virkamiespelkoa, joka näkyy siinä, että maahanmuuttaja ei uskalla sanoa asiasta omaa mielipidettään. Teemahaastatteluun osallistuneiden työntekijöiden mukaan työvoimahallinnossa kotoutumissuunnitelma tarkistetaan joka käynnillä ja sitä muutetaan tarvittaessa.Tämä on yleistä eritoten konstruktivistisen orientaation omaavassa ohjauksessa, sillä ohjauksessa on aina esillä tavoitteiden arviointi ja arvioinnissa pyritään ohjaamaan ohjattavaa hänen tavoitteidensa suuntaisesti. (Vänskä ym. 2011, 135.)

\section{INTERKULTTUURISEN OHJAUKSEN ORIENTAATIOISTA}

Interkulttuurisessa orientaatiossa on nähtävissä vaikutteita kaikista näistä edellä mainituista orientaatioista. Inter- 
kulttuurinen orientaatio on tavallaan yhteistyön lähtökohta, joka tutkimukseen osallistuneiden työntekijöiden mukaan vaatii ohjaajalta tietynlaisen asenteen. Työntekijältä vaaditaan taitoa ymmärtää kulttuurin vaikutus ohjausprosessissa ja ajan myötä ohjaajan interkulttuurinen orientaatio kehittyy maahanmuuttajan ohjausprosessin aikana.

Tutkimustulokseni osoittavat, että maahanmuuttajien ohjauksessa yhdistyivät useat orientaatiot. Interkulttuurinen ohjaus on prosessi, jossa erilaiset orientaatiot vaihtelevat maahanmuuttajan ohjautuvuuden vaiheen ja ohjauksen etenemisen mukaan. Tekemäni tutkimus tukee näkemystä eklektisestä tai integratiivisesta lähestymistavasta, jossa työntekijä yhdistää useita teorioita yhdeksi kattavammaksi teoriaksi. Lähestymistavan avulla voidaan vastata joustavasti maahanmuuttajan tarpeisiin huomioiden maahanmuuttajan ohjautuvuuden vaihe ja ohjauksen eteneminen.

Tutkimukseni tuloksissa on paikannettavissa yhteneväisyyttä aikaisempien interkulttuuriseen ohjaukseen liittyvien tutkimusten kanssa (esim. Constantine 2001; Sue ym. 1996). Interkulttuurinen orientaatio voidaan nähdä kokoavana viitekehyksenä, jonka sisällä ohjaaja voi hyödyntää myös muiden ohjauksen lähestymistapojen ja menetelmien mahdollisuuksia. Kuten Constantinen (2001) niin myös oman tutkimukseni mukaan ne ohjaajat, jotka pystyvät yhdistelemään erilaisia ohjauksen orientaatioita, ymmärtävät paremmin monikulttuurisia asiakkaita. Maahanmuuttajien ohjauksessa työntekijät pyrkivät siihen, että ohjaajan ja ohjattavan välille syntyisi yhteistyösuhde, joka pe- rustuisi erilaisuuden kunnioittamiseen ja maahanmuuttajan itseohjautuvuuteen. Tutkimukseen osallistuneet työntekijät kokivat, että ohjaustilanteessa pitää olla herkkyyttä ja ammattitaitoa nähdä maahanmuuttajan tilanne, kotoutumisprosessin ja ohjautuvuuden vaihe. Tällöin ohjaaja osaisi valita oikean orientaation ja ohjaaja voisi edistää maahanmuuttajan itseohjautuvuutta. Jäykällä toiminnalla ohjaaja voi olla kehittymisen esteenä.

Työntekijät kertoivat, että he joutuvat miettimään, mitä menetelmää he ohjauksessa käyttävät, jotta asia tulee ymmärretyksi. Tämä kuvastaa Eeva Liukon (2006, 11-12) tulkintaa siitä, että kun ammattikäytäntö konkretisoituu toiminnaksi työorientaation kautta, niin ammattikäytäntö ja työorientaatio asettavat reunaehtoja sille, minkälaisia työmenetelmiä ja työvälineitä on mahdollista hyödyntää, miten niitä sovelletaan ja minkälaiseksi palveluvalikko rakentuu. Tällöin ohjaajien joustavuus käyttää ohjauksessa erilaisia näkökulmia ja tekniikoita saattaa edesauttaa ohjauksen onnistumista (Constantine 2001). Interkulttuurinen ohjaus muovaa työntekijän käyttämiä orientaatioita. Myös tietyn orientaation omaava työntekijä muokkaa ohjauksen sisältöjä, mikäli tämä on ohjaukseen käytettävien resurssien puitteissa mahdollista.

Tutkimusten mukaan ohjaajan ikä ja työkokemus ovat tärkeitä teoreettiseen orientaatioon vaikuttavia tekijöitä (Sundland 1977). Tutkimuksessani näkyi työntekijöiden iän myötä tuleva elämänkokemuksen tuoma ammatillisen identiteetin vahvistuminen sekä tiedon ja taidon lisääntyminen. Verrattuna nuoriin alle 35-vuotiaisiin työn- 
tekijöihin yli 56-vuotiaat työntekijät kokivat tuntevansa paremmin Suomen yhteiskunnan palvelujärjestelmän, maahanmuuttajan kulttuuritaustan sekä tietävänsä paremmin, missä asioissa maahanmuuttaja tarvitsee ohjausta. Esimiehiltä ja työkavereilta opittujen työtapojen ja taitojen merkitys ei enää ollut heille niin merkittävä.

\section{MaAhanmuUtTajIEN OHJaUKSEN KEHITTÄMISTARPEITA}

Tutkimukseeni osallistuneet työntekijät kokivat, että maahanmuuttajien ohjauksessa olisi oltava tarpeeksi resursseja. Tämä resurssikysymys tuli ilmi jo 1990-luvun lopulla tehdyissä tutkimuksissa (Lairio ym. 1999). Rajalliset resurssit vaikuttavat siihen, että työntekijöillä ei ole mahdollisuutta kehittää ohjausta vaan työntekijät tekevät ohjausta annettujen resurssien puitteissa. Kehittämistarpeina työtekijät kokivat aika- ja taloudellisten resurssien sekä erilaisia kulttuuritaustoja koskeva tiedon lisäämisen ja ammattitaidon parantamisen. Maahanmuuttajien ohjauksen pitäisi olla nykyistä pitkäjänteisempää, oikea-aikaista, tavoitteellista ja tämänhetkistä prosessinomaisempaa. Vaikka yhteistyö eri viranomaisten välillä onnistuu pääsääntöisesti hyvin, yhteistyötä ja verkostoitumista tarvittaisiin työntekijöiden mukaan silti lisää ja eri tahojen vastuut olisi määriteltävä selvästi. Maahanmuuttajan ohjausketjun olisi hyvä pysyä katkeamattomana, jotta maahanmuuttajat eivät putoaisi pois ohjauksen piiristä. Myös salassapitosäädökset koetaan usein ongelmaksi viranomaisten ja muiden toimijoiden välisessä vuorovaikutuksessa.
Maahanmuuttajaryhmien heterogeenisuus oli tekijä, joka kävi ilmi niin teemahaastatteluissa kuin myös nettikyselyyn osallistuneiden työntekijöiden vastauksissa. Tutkimukseen osallistuneet työntekijät toivoivatkin mahdollisuutta saada lisää koulutusta ja työnohjausta, jotta he voisivat vastata maahanmuuttajien ohjauksessa esiintyviin haasteisiin. Työntekijöiden mukaan he joutuvat itse melko pitkälti etsimään ja kysymään tietoa eri kulttuureista ja monikulttuurisesta ohjauksesta.

\section{LOPUKSI}

Yhteiskunta on jatkuvassa muutoksessa. Sen myötä myös työelämä muuttuu, jolloin tarvitaan uusia ammattiryhmï ja työvoimahallinnon ja aikuiskoulutuksen työntekijöiden työnkuvat muuttuvat. Myös viime aikoina lisääntyneet pakolaisten ja turvapaikanhakijoiden määrät ja laiton maahanmuutto lisäävät maahanmuuttajien kanssa työskentelevien työntekijöiden ja työn määrää. Maahanmuuttajaohjaajan ja -neuvojan työ on hyvä esimerkki tästä kehityksestä. Tällöin monikulttuurisen ohjauksen asiantuntijuuden ja ammattitaidon määrittely, ammattitaitovaatimusten asettaminen, ammatillinen erikoistuminen ja sitä kautta mahdollisimman selkeän ammatti-identiteetin kehittäminen ovat tulevaisuuden haasteita, joiden tarkastelussa tarvitaan tutkimustietoa. (Koivumäki \& Oinonen 2013, 362.) Lisäksi moni- ja interkulttuurinen ohjaus on yksi nopeimmin kasvavia ohjauksen osa-alueita (Lairio ym. 1999, 127; Pedersen 1991).

Tutkimukseni tulokset antavat yhden esimerkin siitä, millainen maahan- 
muuttajien ohjaus voisi prosessina olla. Tutkimukseni tuottaa myös tieteellistä tietoa siitä, millaisena työvoimahallinnon ja aikuiskoulutuksen työntekijät kokevat maahanmuuttajien ohjauksen sekä millaisia ohjauksen orientaatioita ohjausprosessissa on paikannettavissa. Erään haastatteluun osallistuneen työntekijän lausahdus: "kädestä pitäen vierellä kulkijaksi", kuvaa hyvin tutkimuksen tuloksissa esille tullutta ohjausprosessia.

Tutkimuksessani interkulttuurinen ohjaus näyttäytyi praktisena, innovatiivisena ja monimuotoisena. Maahanmuuttajille ohjausta antavissa työpaikoissa tämä edellyttää toimintaympäristön tukea työntekijöille. Työpaikalla organisaation täytyy olla sitoutunut monimuotoisesti ja innovatiivisesti kohtaamaan erilaisten asiakkaiden tarpeet ja miettimään niihin ratkaisut. Tällöin on tärkeää, että työntekijä tietää, keneltä tai mistä voi tarvittaessa kysyä neuvoja ja että työntekijällä on mahdollisuus kokeilla erilaisia ohjausmenetelmiä.

Jatkossa ohjauksen merkitys tulee korostumaan myös muiden kuin maahanmuuttajien osalta. EU:ssa jäsenmaat ovat kiinnittäneet erityistä huomiota ohjaustukea tarvitseviin riskiryhmiin kuten syrjäytymisuhan alaisiin nuoriin, vähäisen osaamisen hankkineeseen yli 50-vuotiaaseen väestöön, maahanmuuttajiin ja etnisiin ryhmiin. Yleinen trendi EU:n jäsenmaissa näyttää olevan riskiryhmiin kuuluvien asiakkaiden henkilökohtaisen ohjauksen lisääminen. (Launikari 2013, 161.) Esimerkiksi syrjäytymisvaarassa olevat nuoret tarvitsevat ohjausta koulutukseen ja työllistymiseen. Tutkimukseni tuloksia prosessinomaisesta ohjauksesta voidaan hyödyntää yleisemminkin kuin maahanmuuttajien ohjauksessa, esimerkiksi sosiaalityön asiakasprosesseissa asiakkaiden ohjauksessa tai erityistä tukea tarvitsevien opiskelijoiden ohjauksessa.

Näin ollen tutkimustieto ohjauksesta ja tutkimusperusteinen tieto ohjauksessa käytettävistä työmenetelmistä on tarpeellista ja jopa välttämätöntä. Jatkossa olisi tärkeää tutkia myös maahanmuuttajien näkemyksiä heidän saamastaan ohjauksesta.

Tulevaisuudessa selviää, kuinka maakuntauudistuksen myötä työvoima- ja yrityspalveluiden uudistus vaikuttaa maahanmuuttajien ohjaukseen. Mikä vaikutus suunnitellulla nykykaltaisten työ- ja elinkeinotoimistojen lakkauttamisella ja palveluiden järjestämisvastuun siirtymisellä maakunnille on maahanmuuttajien ohjaukseen? Onko työntekijöillä jatkossa riittävästi aikaa maahanmuuttajien ohjaukseen ja muuttuuko ohjaus prosessinomaisemmaksi, kuten tutkimukseeni osallistuneet työntekijät toivoivat?

Kirjoitus perustuu kirjoittajan Itä-Suomen yliopistossa 2.3.2018 pitämään lectio praecursoriaan.

\section{Kirjallisuus}

Constantine, Madonna G. (2001) Multicultural Training, Theoretical Orientation, Empathy, and Multicultural Cade Conceptualization Ability in counsellors. Journal of Mental Health Counselling 23(4), 357-372.

Grow, Gerald (1996) Teaching Learners to be Self-Directed. Adult Education Quarterly, 41(3), 125-149. https://doi. org/10.1177/0001848191041003001

Jensen, Jay P. \& Bergin, Allen E. \& Greaves, David W. (1990) The meaning of eclesti- 
cism: New survey and analysis of components. Professional Psychology: Research and Practice 21 (2), 124-130. https:// doi.org/10.1037//0735-7028.21.2.124

Juhila, Kirsi (2006) Sosiaalityöntekijöinä ja asiakkaina. Sosiaalityön yhteiskunnalliset tehtävät ja paikat. Tampere:Vastapaino.

Kuusinen, Kirsti-Liisa (2000) Kognitiivinen psykoterapia ohjauksen viitekehyksenä. Teoksessa Jussi Onnismaa, Heikki Pasanen \& Timo Spangar (toim.) Ohjaus ammattina ja tieteenalana 1. Ohjauksen lähestymistavat ja ohjaustutkimus. Jyväskylä: PS-kustannus, 83-105.

L 493/1999: Laki Maahanmuuttajien kotouttamisesta.

L 1386/2010: Laki kotoutumisen edistämisestä.

Lairio, Marjatta \& Puukari, Sauli \& Varis, Eija (1999) Oppilaanohjaus maahanmuuttajaoppilaiden tukena. Teoksessa Kaija Matinheikki-Kokko (toim.) Monikulttuurinen koulutus - perusteita ja kokemuksia. Helsinki: Opetushallitus, 127-143.

Launikari, Mika (2013) Monikulttuurinen Euroopan unioni - ohjauspalveluiden kehittäminen kansalaisten tarpeisiin. Teoksessa Vesa Korhonen \& Sauli Puukari (toim.) Monikulttuurinen ohjaus ja neuvontatyö. Jyväskylä: PS-kustannus, 157-170.

Lehtinen, Esko \& Jokinen, Tuija (1996) Tutor - itsenäistyvän oppijan ohjaaja. Helsinki:WSOY.

Lindberg, Annina (2013) Eväitä arviointiin sosiaali ja terveysjärjestöissä. Helsinki: Suomen mielenterveysseura. https:// www.mielenterveysseura.fi/sites/default/files/inline/horisontti_evaita_arviointiin_0114.pdf>.31.1.2018

Liukko, Eeva (2006) Kuntouttavaa sosiaalityötä paikantamassa. SOCCA:n ja Heikki Waris -instituutin julkaisusarja 9/2006. Helsinki: SOCCA ja Heikki Waris -instituutti.

Mönkkönen, Kaarina (2002) Dialogisuus kommunikaationa ja suhteena. Vastaamisen, vallan ja vastuun merkitys sosiaalialan asiakastyön vuorovaikutuksessa. Kuopion yliopiston julkaisuja E, Yhteiskuntatieteet 94. Akateeminen väitöskirja. Kuopio: Kuopion yliopisto.

Norcross, John C. \& Hedges, Melissa \&
Castle, Patricia H. (2002) Psychologists conducting psychotherapy in 2001: A study of the Division 29 membership. Psychotherapy: Theory, Research, Practice, Training 39 (1), 97-102. https://doi. org/10.1037//0033-3204.39.1.97

Peavy, Vance R. (1999) Sosiodynaaminen ohjaus. Konstruktivistinen näkökulma 21. vuosisadan ohjaustyöhön. Suomennos Petri Auvinen. Helsinki: Psykologien kustannus Oy.

Pedersen, Paul B. (1991) Multiculturalism as a generic approach to counselling. Journal of Counselling \& Development 70 (1), 6-12.

Puukari, Sauli \& Korhonen Vesa (2013) Monikulttuurisen ohjauksen lähtökohdat. Teoksessa Sauli Puukari \& Vesa Korhonen (toim.) Monikulttuurinen ohjaus ja neuvontatyö. Jyväskylä: PS-kustannus, 72-93.

Sisäministeriö (2015) Maahanmuuton ja kotouttamisen suunta 2011-2014. Sisäministeriön julkaisu 2/2015. http:// URN:ISBN:978-952-324-012-4

Sue, Derald W. \& Ivey, Allen E. \& Pedersen, Paul B. (1996) A theory of multicultural counselling and therapy. Pacific Grove, CA: Books/Cole.

Sundland, Donald M. (1977) Theoretical orientations of psychotherapists. Teoksessa Alan S. Gurman \& Andrew M. Razin (toim.) Effective psychotherapy: A handbook of research. NewYork: Pergamon, 189-219.

Vänskä, Kirsti \& Laitinen-Väänänen, Sirpa \& Kettunen, Tarja \& Mäkelä, Juha (2011) Onnistuuko ohjaus? Sosiaali- ja terveysalan ohjaustyössä kehittyminen. Helsinki: Edita Prima.

Worthington, Roger L. \& Atkinson, Donald R. (1993) Counsellors' responsibility and etiology attributions, theoretical orientations, and counselling strategies. Journal of Counselling Psychology 40 (3), 295302 . https://doi.org/10.1037/00220167.40.3.295

Worthington, Roger L. \& Dillon, Frank R. (2003) The theoretical orientation profile scale-revised: A validation study. Measurement and Evaluation in Counselling and Development, 36 (2), 95-105. 